\title{
Scrutiny on Indonesian EFL Teachers' Willingness to Understand and Implement the TPACK in VLE
}

\author{
ST. Ayu Surayya ${ }^{1 *}$,Maman Asrobi ${ }^{2}$, Zukhruf Farizi ${ }^{3}$ (D) \\ ${ }^{1,2,3}$ English Language Education Department,Hamzanwadi University, Pancor, Indonesia
}

\section{A R T I C L E I N F O}

Article history:

Received October 01, 2021

Revised October 02, 2021

Accepted November 06, 202

Available online November 25, 2021

Kata Kunci:

Pengetahuan Teknologi, TVE, Kesediaan, TPACK

Keywords:

Technological Knowledge, TVE,

Willingness, TPACK

DOI:

https://dx.doi.org/10.23887/jet.v5i4. 40986

\begin{abstract}
A B S T R A K
Di masa pandemi ini, semua negara fokus pada isu untuk mentransformasi system pendidikan, media, strategi mengajar dan materi, dari pengajaran dan pembelajaran tatap muka menjadi pembelajaran berbasis Teaching in a Virtual Environment (TVE), termasuk di Indonesia. Akan tetapi, perubahan situasi yang mendadak ini membuat semua sistem pendidikan berubah secara terburu-buru. Fakta bahwa guru-guru Bahasa Inggris lebih mahir pada penerapan pengetahuan konten dan pedagogis mereka dibandingkan pengetahuan teknologi membuat penelitian ini bertujuan untuk menentukan bagaimana kesediaan guruguru untuk menambah dan mengaplikasikan TPACK mereka, khususnya pada TVE pada saat ini, dan juga mengungkapkan pengaruh kesediaan meningkatkan TPACK dengan kesediaan menerapkan TPACK. Responden dalam survey ini adalah 43 guru EFL. Instrumen yang digunakan dalam mengumpulkan data yaitu kuesioner. Dalam analisis data kuantitatif yang digunakan adalah statistic deskriptif, uji normalitas dan homogenitas, serta uji-t independen. Data menunjukkan bahwa sebagian besar guru EFL Indonesia berada ditingkat median dalam kesedaiaannya untuk belajar dan mempraktekkan TPACK. Namun, tidak ada hubungan antara kesediaan untuk memahami dan kesediaan untuk menerapkan TPACK di kalangan guru bahasa Inggris. Temuan ini mempengaruhi perspektif pendidik dan peneliti tentang bagaimana tekanan dari luar perlu untuk dikurangi dan guru-guru di Indonesia membutuhkan motivasi internal terhadap pendidikan berbasis teknologi.
\end{abstract}

\section{A B S T R A C T}

During this pandemic, all countries focused on the issue of transforming the education system, media, teaching strategies, and materials, from face-to-face teaching and learning to teach in a Virtual Environment (TVE)-based, including in Indonesia. However, this sudden change of situation made all education systems change in a hurry. The fact that English teachers are more proficient at applying their content and pedagogical knowledge than technological knowledge makes this study aim to determine how willing teachers are to add and apply their TPACK, particularly in TVE at the moment, and also to reveal the effect of willingness to increase TPACK with a willingness to apply TPACK. The respondents in this survey were $43 \mathrm{EFL}$ teachers. The instrument used in collecting data is a questionnaire. Descriptive statistics, normality and homogeneity tests, and independent t-tests were used in the quantitative data analysis. The data shows that most Indonesian EFL teachers are at the median level of readiness to learn and practice TPACK. However, there is no relationship between willingness to understand and willingness to apply TPACK among English teachers. This finding influences the perspective of educators and researchers on how external pressures need to be reduced and teachers in Indonesia to need internal motivation towards technology-based education.

This is an open access article under the CC BY-SA license. Copyright (C) 2021 by Author. Published by Universitas Pendidikan Ganesha.

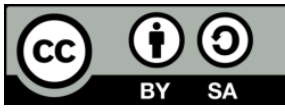

\section{INTRODUCTION}

The impact of the COVID-19 epidemic on the global educational system cannot be overstated. The high risk of virus spread without a clear timeline (Alateeq et al., 2020; Clark et al., 2020) when this pandemic will stop makes traditional school-based teaching forces educators to work extra hard to keep the education process going even when teaching and learning from home. From a state of ignorance about virtual learning, most people are now aware of it, and it has become a new culture (Teräs et al., 2020; Wijaya et al., 2021). As a result, the online system that they employed in casual situations and unscheduled meetings has become a key face-to-face substitute in this pandemic. Online-based teaching strategies, media, and textbook become the most noticed thing now by the teachers who has a demand to be able to adapt their prior knowledge to be used in new learning circumstance. The using of technology in online learning is also explored by teachers in their 
classrooms and it can be a powerful tool to support students' creativity-relevant motivation and learning engagement, idea development and exploration, creation, as well as giving students an option to employ their learning work assets in other digital media, making foreign language learning more stimulating ((Bereczki \& Andrea, 2021; Klimova, 2021). Thus, in this situation, teacher must be able to adapt any situation with proactive strategies, find a clear, consistent, and clear rule to keep in touch with the students without elusory to redirect their disobedience, and find a clear, consistent, and clear rule to keep in touch with the students without elusory to redirect their disobedience (Graham et al., 2020; Sieberer-Nagler, 2015). The success of their students relays on the teachers' competency to use digital technology in pedagogical concern (Barni et al., 2019; Li, 2021). Furthermore, other research found the relationship between teachers' cognitive self-concept and their willingness to destruct challenging situation and academic changing (Low et al., 2019; Syahputra et al., 2017).

However, the global Covid-19 pandemic has had a wide range of institutional and behavioral shock repercussions in various areas of human movement, including schooling (Teräs et al., 2020). It conveys the impression that the educational system, which includes the educational ministry, teachers, and students, is rushing to study online tactics and media (Brief, 2020; Oyedotun, 2020). Even more, in Indonesia, technology integration just becomes the country's widely recent concentration in education. This accidently transformation builts a question about the teachers' willingness to move their habitual face-to-face education to the new virtual education system in which relay on technology, whereas, when teachers felt less external pressure and were more self-determined in their teaching, their relationships were stronger (Barni et al., 2019; Savina, 2015). On the other part, TPACK can be used to determine a teacher's qualification and competency in online learning. Technologies Knowledge (TK), Pedagogical Knowledge (PK), Content Knowledge (CK), Technology Pedagogical Knowledge (TPK), and Technology Content Knowledge (TCK) are all part of TPACK (TPACK). TPACK is the answer to all-must-have needs for a teacher in an online learning session, founded in 2006 by Mishra and Koehler. This concept emphasizes knowledge as a critical component of innovation in integrating various kinds of technology into learning activities (Batiibwe \& Bakkabulindi, 2016; Prasojo et al., 2020). And it is required a comprehensive understanding of the synergy between technology,pedagogy, and content, as well asadaptive and purposeful use of various educational resources for the sustainability and effectiveness of technology use in learning (Viera \& Sánchez, 2020;(Maican \& Cocoradă, 2021).

In today's study, TPACK has become a prominent topic. Recent mosquitoes research has discovered that EFL teachers have a good TPACK score (Ciptaningrum, 2017; Prasojo et al., 2020; Nazari et al., 2019) even though they have low self-efficacy to implement the TPACK in teaching (Cahyono et al., 2016). To be more specific, teachers' TPACK on writing are in moderate level. If teachers' TPACK is examined in a broad sense, it suggests they have a decent degree of TPACK, but it is difficult for them to adapt their specialized content knowledge to specific technology (Ammade et al., 2020; Surayya \& Asrobi, 2020). The findings revealed that Education Technology graduates possessed a strong grasp of subject and pedagogical competence (Utama's, 2019). Their ability to use technology, on the other hand, was still lacking. However, the use of technology to facilitate learning is gaining traction across many educational institutions (Sharma \& Srivastava, 2020). Limited studies investigate teachers' self-concept (Low et al., 2019) and those research above didn't reveal that how the EFL teachers' willingness to add their understanding and implementing the TPACK quantitatively. On the other hand, it is worthwhile to investigate how TPACK implementation and comprehension are linked to EFL teachers' willingness to participate in this hard VLE, as stated that is a good choice to play a role in discovering what variables can motivate teachers to face a problem (Alshenqeeti, 2018;Barni et al., 2019). As a result, it becomes appropriate to discuss the willingness prerequisites that may have an impact on the rapidly growing VLE.

\section{METHOD}

This research is a quantitative study based on the distribution of a questionnaire to a large number of EFL teachers. The goal of survey research is to statistically define a certain aspect of a targeted study, as well as to investigate the relationship between some variables. Survey is suitable for use in future longitudinal studies of TPACK in educational contexts. Thus, this study employed a survey method within 45 EFL teachers in Indonesia from west to the center parts of Indonesia. The clear process used in this study was showed in the Figure 1 below. The population of this study includes EFL teachers in Indonesia at two levels of institution: junior and senior high school, both private and public, and the sample are 15 male and 28 female EFL instructors from Java, Borneo, and West Nusa Tenggara who have taught for 1 to 20 years. While this study favors a quantitative approach, there are no restrictions on the number of people who can participate. As a result, the term "insidental sampling" is used in this work. Insidental sampling is the process of establishing a sample technique based on chance (Sugioyono, 2011:67). Whoever meets the researcher insidentally can be choosen as the sample if they are seen as the proper participants who meet the criteria as data sourching. Aside from that, the sample includes whoever is willing to respond to an online questionnaire sent to their WhatsApp message. 
Figure 1. The steps of this study

However, based on the Figure 1, a questionnaire was created by altering the Fuad et al., (2020) and Schmidt et al., (2010) questionnaires to reflect the findings concerning instructors' readiness to enhance and apply their TPACK, the questionnaires consisted of 13 questions for revealing willingness to understand the TPACK and 11 questions for revealing the willingness to implement the TPACK. After the English questionnaire was translated into Bahasa Indonesia, three experts checked the substance and language of both the English and Bahasa Indonesia questionnaires. The first expert was pursuing a doctorate in Australia, the second was an experienced educational surveyor, and the third was an Indonesian professor who had previously published a TPACK research piece in an international publication.

Table 1. Grid of Test Questionnaire

\begin{tabular}{|c|c|c|c|c|}
\hline \multirow[t]{2}{*}{ KD } & \multicolumn{2}{|l|}{ Willingness to Understand the TPACK } & \multicolumn{2}{|c|}{ Willingness to Implement the TPACK } \\
\hline & Indicators & Items & Indicators & Items \\
\hline TK & $\begin{array}{l}\text { Willing to learn how to solve a technical } \\
\text { problem and willing to try new } \\
\text { technology }\end{array}$ & 1,2 & $\begin{array}{l}\text { Willing to use technology, spend } \\
\text { time, and keep up with it }\end{array}$ & $3,4,5$ \\
\hline CK & Willing to add English knowledge & 6 & $\begin{array}{l}\text { Willing to use various ways to } \\
\text { develop English content and use it } \\
\text { every day }\end{array}$ & 7,8 \\
\hline $\begin{array}{l}\text { PK in } \\
\text { VLE }\end{array}$ & $\begin{array}{l}\text { Willing to add knowledge about } \\
\text { teaching in VLE }\end{array}$ & 9 & Willing to add & 10 \\
\hline PCK & $\begin{array}{l}\text { Willing to adjust teaching that needed } \\
\text { by students }\end{array}$ & 11 & $\begin{array}{l}\text { Willing to teach English material } \\
\text { that needed by student }\end{array}$ & 12 \\
\hline TCK & $\begin{array}{l}\text { Willing to learn technology to } \\
\text { understand English language material }\end{array}$ & 13 & $\begin{array}{l}\text { Willing to use technology as the } \\
\text { media to learn CK }\end{array}$ & 14 \\
\hline TPK & $\begin{array}{l}\text { Willing to find out and think critically } \\
\text { about teaching to enhance student } \\
\text { learning and effective teaching }\end{array}$ & $\begin{array}{l}15,16 \\
18\end{array}$ & $\begin{array}{l}\text { Willing to adjust technology from } \\
\text { various teaching activities }\end{array}$ & 19 \\
\hline & $\begin{array}{l}\text { Online teaching makes thinking the use } \\
\text { of technology in class }\end{array}$ & 17 & & \\
\hline TPACK & $\begin{array}{l}\text { Willing to find out technology in online } \\
\text { class that enhances content for English } \\
\text { subject. }\end{array}$ & 20,21 & $\begin{array}{l}\text { Willing to teach, use strategies, and } \\
\text { help other collegues by combining } \\
\text { English, technology and teaching } \\
\text { approach in online class }\end{array}$ & $\begin{array}{c}22,23, \\
24\end{array}$ \\
\hline
\end{tabular}

After being transformed into an online questionnaire, it was tested on at least 30 EFL instructors for two weeks using an English questionnaire, then the test results were validated by using Pearson validity test with $\mathrm{r}_{\text {table }}$ $5 \% \mathrm{n}=30=0.361<\mathrm{r}_{\text {count }}$. The result showed that all 24 items have $\mathrm{r}_{\text {counting }}$ more than the $5 \% \mathrm{r}_{\text {table }}$ and the relieability score is 0,951 . Then, after being answered by 43 different EFL teachers he questionnaire was written in the online survey form https://forms.gle/Z85brDtmudChscT7. Because of the prevalence of online learning in this era, the ideal way to collect data is to send the survey link to some school advisors, academic colleagues, and to share the survey link on social media by tagging some familiar EFL teachers. The data gathering was place over the course of two weeks. The results of the questionnaire for EFL teachers are not directly assessed. The data had to be divided into two groups: "willingness to grasp the TPACK" and "willingness to apply their TPACK," after which the overall score each EFL teacher was calculated by multiplying the score by a 
percentage. The data for each group was then statistically described. Using Azwar (2012) data categorization, the frequency was also counted to rate the group into three categories: low, middle, and high.

Since the purpose of this study is to see if a high level of teacher TPACK correlates with their readiness to add to their knowledge and utilize it in their teaching, the researchers employed a two-way analysis. The first is a descriptive analysis using SPSS 26.0, and the second is an inferential study. In inferential analysis, it revealed the normality test by using kolmogorov-smirnov one sample test. However, in hypothesis test, the criteria to refuse and accept the $\mathrm{H}_{\mathrm{o}}$ based on P-Value or Signature (Sig) is if $\mathrm{Sig}<0,05$, so $\mathrm{H}_{\mathrm{o}}$ is refused or the data was not distributed normally and if $\mathrm{Sig} \geq 0,05$, so $\mathrm{H}_{\mathrm{o}}$ is accepted or the data was distributed normally. Beside normality test, the homogeneity test was used to see whether the population is homogeny or not. In this study, the homogeneity was done by using Homogeneity of Variance Test in One-Way Annova by using SPSS 26,0 version. Last, the t-independent test was used to see whether there is average in the two couple samples and it can be used to see whether the existence of difference between the two sample groups, the EFL teachers willingness to understand the TPACK and willingness to implement the TPACK. Regarding the independent sample T-test, it also used the SPSS 26.0 version.

\section{RESULT AND DISCUSSION}

\section{Result}

The purpose of this study is to quantify Indonesian EFL instructors' willingness to grasp the TPACK and their willingness to implement their TPACK in a VLE, thus it was necessary to display the statistical results. Although the results of this study about the willingness in TPACK cannot be compared to previous research on the same topic because it is a new study, some closely related previous research about technology involvement in education and teachers' willingness in education innovation may be suitable cases to be fitted and connected. For the first question about the teachers' willingness to understand theirTPACK, the survey result showed that most of the EFL teachers have middle willingness. The average readiness to grasp the TPACK score is 88 out of 43 responders, with a high score of 97-100. More specifically, 63 percent of Indonesian EFL teachers have a moderate willingness to comprehend the TPACK, whereas $23 \%$ have a strong willingness to understand the TPACK, and just $14 \%$ have a poor willingness to understand the TPACK. As can be seen from the data, the majority of EFL teachers show a moderate willingness to learn about the TPACK. The willingness understand and enhance their rank and place is closely described as willingness to understand. With a moderate desire to explore some further information about TPACK in the VLE, 63 percent of the teachers signed the survey. This phenomena was also evident in the question, "I am willing to find a technology that will enable me to be more effective in my online study." It refers to the question with the fewest responses from teachers, and it has to do with Bloom's taxonomy's "analyze" level, which is in the upper part of the levels. This level required students to connect numerous ideas and then apply their critical thinking skills to create new information (Hyder \& Bhamani, 2016). Other questions, such as "I am willing to find out technology that enhances content for an English subject," "I am willing to find out a technology to use in the classroom that enhances what I teach, how I teach, and what students learn," and "I am willing to spend my time thinking critically about how to use technology in the classroom," which refer to questions to dig the teachers' critical thinking, have become the secondary choice of the teachers rather than the primary choice of the teachers.

Regarding to the second question, it showed that the teachers' willingness in implementing the TPACK is quite similar with their willingness to add the TPACK in VLE. Despite the fact that this score is down around $3 \%$, Indonesian EFL teachers' readiness to execute their TPACK is still in the center, with an average score of 85. According to table 2, $60 \%$ of Indonesian EFL teachers have a middle willingness to grasp the TPACK, only $21 \%$ have a high desire to understand the TPACK, and only $19 \%$ have a low willingness to implement the TPACK. Last, the answer of the third question about the correlation between willingness to implement and willingness to adjust TPACK. The significance score for willingness to comprehend TPACK is $0.200>0.05$, and the significance score for willingness to apply TPACK is $0.103>0.05$, according to the normality analysis utilizing the One-Sample Kolmogorov-Smirnov Test. As a result, the readiness to comprehend TPACK data and the willingness to execute TPACK are normaly distributed. The Sig score of willingness to undrstand and implement the TPACK is $0.677>0.05$, according to the homogeneity analysis using the One-way Anova test. This score indicates that the understanding and implementation of the TPACK have the same version or homogeny. Based on the criterion to accept and refuse the $H_{0}$ following the PValue or Significance (Sig) that "if the Sig is 0,05 , then $H_{0}$ is refused and if Sig is 0,05 , then $H_{0}$ is accepted," $H_{0}$ is accepted and $H_{a}$ is refused with the $\mathrm{p}$ value $\mathrm{t}$ test independent test of 0.1260 .05 . As a result, the willingness of EFL teachers to grasp the TPACK has little bearing on their willingness to adopt the TPACK in the VLE. 


\section{Discussion}

Teachers, on the other hand, were eager to help students with the understanding level, which is the second level of Bloom. It was demonstrated by the question, "I am willing to contribute my understanding of teaching techniques to the VLE." It received the highest score, with $62,8 \%$ of teachers responding strongly agree and $32,6 \%$ responding agree. The teachers are willing to use Scientific Approach in Indonesia several ago. Teachers, he discovered, have some learning exercises to supplement their understanding of the new curriculum. They had a discussion, training, and instruction session on how to incorporate a Scientific Approach into the classroom (Abidah et al., 2020; Syahputra et al., 2017). The research focuses on the impact of students, teachers, parents, and faculty members on the "Merdeka Belajar" or "freedom learning" program (Abidah et al., 2020). It is a pandemic preparedness program supported by the Indonesian Ministry of Education and Culture (MOEC). Negative feedback comes directly from students and teachers. One of the pupils remarked that learning from home made his academic load greater, and that his teacher chose to surrender rather than educate his class. The contribution of teachers in TVE was also acknowledged by the other pupils. He said that the lecturers only provided the students the title of the material and then instructed them to learn using the device. Furthermore, the parent expressed his concern with the term "freedom", where he frightened that by "freedom," he meant freedom without bounds.

In contrast, the unfavorable opinions of parents and students are considerably different from the viewpoints of teachers and faculty members. Teachers and faculty members were enthusiastic about the government's new initiative. The faculty member described it as "a breath of fresh air" for TVE, with teachers claiming that the Teacher's Room application and MOEC page can be used to learn about any subject. Another faculty member, on the other hand, expressed his satisfaction with the fact that students can improve themselves through independent learning using existing online learning resource capabilities. These good responses from instructors and faculty members, however, cannot be understood because the teachers were asked directly without being anonymously interviewed (Abidah et al., 2020). As a result, what students thought about their teachers did not match to what teachers thought about their capability, as (Fiarman, 2016; Tseng, 2014). This moderate willingness to comprehend the TPACK give a sign that Indonesian EFL teachers are aware of the importance of technology in TVE. They were well aware that TVE today need more competent teachers who are up to date on current events and trends. As a result, failing to integrate their expertise with pedagogy, concept, and technology means becoming stuck in one spot and unable to progress. However, they do not make it a top priority in their lives to include technology. Only $23 \%$ of Indonesian EFL teachers agreed to participate. If this willingness is linked to Bloom's taxonomy, the teachers' willingness is determined by the level of difficulty involved in carrying out the action. The teachers were extremely willing to do it if it was merely to contribute some knowledge in order to grasp the TPACK without dissecting it.

The moderate desire to adopt the TPACK, on the other hand, Indonesian teachers have low self-efficacy to implement the TPACK in teaching (Cahyono et al., 2016; Wijaya et al., 2021). Teachers' self-efficacy was substantially connected with teachers' desire to undertake a curriculum reform and if self-efficacy is poor, teachers will lessen their fear by generating an avoidance of the issue (Pace \& Aiello, 2016; (Bendejo, 2021; Cerit, 2013; Rodríguez et al., 2015). As a result of their poor self-efficacy, Indonesian EFL teachers may be reluctant to adopt the TPACK. The question "I am willing to alter technology that is used in every online learning activity" demonstrates this medium willingness. It is the least popular choice among instructors, with 67,4 percent choosing agree, 27,9 percent choosing very agree, and 4,7 percent choosing less agree. Other questions, such as "I am willing to teach the appropriate subject in my online class by combining English language material, technology, and teaching approaches," and "I am willing to use stategies that combine content, technology, and teaching approach in my online class," were also answered with a majority of yes votes.

Implementation refers to the application level when it comes to Bloom's Taxonomy. It is the application of abstractions to specific and concrete situations (Hyder \& Bhamani, 2016; Sobral, 2021). It is a higher level of area than comprehension and comprehension level, but it is lower than analysis. Based on this structure, teachers add TPACK information, apply it, and then examine it to see if it is appropriate, if it has any flaws, and if it has any vitality. Finally, descriptive analysis, homogeneity test variance, and an independent sample test were used to examine if the Indonesian EFL teachers' willingness to grasp the TPACK has an effect on their implementation of their TPACK. On the other hand, came to a different conclusion. Low et al., (2019) discovered that the relationship between teachers' cognitive self-concept and their readiness to handle challenging students has a substantial impact (Low et al., 2019; Syahputra et al., 2017). Whereas, disclosed that teachers are willing to fully use the scientific approach. They carried it out in accordance with government guidelines (Syahputra et al., 2017). Yet, these findings differ from how teachers in this pandemic deal with the new dramatic shift from face-to-face learning to the VLE. It means that, the self efficacy will have a correlation if it is connected with other problems except the technical problem as what is find in this study and vise versa. How teachers adopt the TPACK in TVE is a true fair issue, because TVE provides an enormously different environment than education past. TVE replaces traditional face-to-face learning with virtual learning, which was 
never expected before and would never be employed if there were no epidemic (Dhawan, 2020; Oyedotun, 2020). The sudden epidemic made teachers feel compelled to learn, despite the fact that the issue was not highlighted by the teacher, and they are still unsure whether this situation would be long-term or short-term. If a teacher chooses to do or not do anything, he will consider the advantages and disadvantages as a subjective standard (Hussain \& Javed, 2019).

However, in the current study, the majority of the teachers investigated are graduate students. The result of the teachers reveal that their knowledge that focuses solely on pedagogy and content knowledge (PK, CK, and PCK) has a better willingness to comprehend and practice it rather than their knowledge that is connected with technology (PTK, CTK, and TPACK). It was expected that they still do not have a lot of time to deal with teaching experience and would rather devote their time to adapting to teacher responsibilities rather than expanding their knowledge of technology as a teacher. Because they use technology in their daily lives, their self efficacy on this task may be strong. In their college, new graduate teachers had a strong desire and positive perception to master teaching aids that integrated pedagogy and curriculum with technology (Fitri \& Putro, 2021; Mohaidat, 2013). Furthermore, for a clear insight, although the willingness to understand and implement the TPACK is on par, but the finding shows that Indonesian EFL teachers' willingness to grasp the TPACK has little bearing on their willingness to put their TPACK into action. EFL teachers' willingness to understand the TPACK is higher than their willingness to implement the TPACK. It means, the EFL teachers in Indonesia has an eagerness to add their knowledge, since they are still new with the TVE. They are rather repressive in their use of technology in their virtual classrooms. But some factors affect their willingness to come up with the technology in real teaching by online. Lack of resuources, like digital inequalities among students, staff and teachers, unavailablelity of computer, laptop and tables for online learning, no internet accessibility lack of personal touch in E-Learning and physical barriers for both students and teachers, e.g., eye strain are some of the reasons why people are less willing to implement the TPACK than they are to add their knowledge (Octaberlina \& Muslimin, 2020; Oyedotun, 2020).

Likewise, from the finding, it can be given a view that Indonesian EFL teachers need more training and adequate technology facilities to build their willingness toward the implementation of TPACK. It is the government's job to provide TVE knowledge. It serves as an external motivator, with the government developing educational programs to support teachers' abilities. The propensity of Indonesian EFL teachers to relay their technical expertise with pedagogical and subject knowledge in TVE may be influenced by their VLE knowledge. As a result, the desire of instructors to adopt or comprehend TPACK in VLE is determined by the education ministry's policy. Yet, the result on this study will not be eternal and final since it is assumed that the new transformation of online learning will be come a new culture several years later then teachers in Indonesia accustomed with it (Wijaya et al., 2021). On the other hand, although, finally from this study we know that EFL Indonesian willingness level in TPACK in middle, same like their level in TPACK itself, it is impossible to say that all instructors with varying levels of experience have the same level of willingness to comprehend and execute their TPACK (Ammade et al., 2020; Cahyono et al., 2016; Surayya \& Asrobi, 2020). Thus, the result of the questionnaire used in this study may be different if it is applied in the other language area where technology become an alter ago, like IT teachers, or even economic, law, science, or health area. Instead, it is not true to say that all EFL teachers in all countries have the same personality of willingness toward the technology as those in Indonesia. As a result, it is proposed that the other knowledge area and other countries reveal their teachers' readiness to grasp and implement their TPACK for further research.

\section{CONCLUSION}

The success TVE comes from the teachers who has a high willingness to add their knowledge and to implement their knowledge. Yet, EFL teachers' in Indonesia are still in grey level whether to be willing or not willing. These two kinds of willingness indeed do not influence each other, but now it is understood that Indonesian EFL teachers need to be more eager to follow education culture chancing, from real class to virtual class.

\section{REFERENCES}

Abidah, A., Hidaayatullaah, H. N., Simamora, R. M., Fehabutar, D., \& Mutakinati, L. (2020). The Impact of Covid-19 to Indonesian Education and Its Relation to the Philosophy of "Merdeka Belajar." Studies in Philosophy of Science and Education, 1(1), 38-49. https://doi.org/10.46627/sipose.v1i1.9.

Alateeq, D. A., Aljhani, S., \& Aleesa, D. (2020). Since January 2020 Elsevier has created a COVID-19 resource centre with free information in English and Mandarin on the novel coronavirus COVID- 19 . The COVID-19 resource centre is hosted on Elsevier Connect, the company' $\mathrm{s}$ public news and information. WHO's Information on Parenting in the Time of COVID-19, January. 
Alshenqeeti, H. (2018). Motivation and Foreign Language Learning: Exploring the Rise of Motivation Strategies in the EFL Classroom. International Journal of Applied Linguistics and English Literature, 7(7), 1. https://doi.org/10.7575/aiac.ijalel.v.7n.7p.1.

Ammade, S., Mahmud, M., Jabu, B., \& Tahmir, S. (2020). TPACK model based instruction in teaching writing: An analysis on TPACK literacy. International Journal of Language Education, 4(1), 129-140. https://doi.org/10.26858/ijole.v4i2.12441.

Barni, D., Danioni, F., \& Benevene, P. (2019). Teachers' self-efficacy: The role of personal values and motivations for teaching. Frontiers in Psychology, 10(JULY), 1-7. https://doi.org/10.3389/fpsyg.2019.01645.

Batiibwe, M. S. K., \& Bakkabulindi, F. E. K. (2016). Technological pedagogical content knowledge ( TPACK ) as a theory on factors of the use of ict in pedagogy: A review of literature. International Journal of Education and Research, 4(11), 123-138.

Bendejo, D. (2021). Teachers ' Self-Efficacy: Why it Matters? Teachers 'Self-Efficacy: Why it Matters? March 2019. https://doi.org/10.13140/RG.2.2.15330.45762.

Bereczki, O., \& Andrea, K. (2021). Technology-enhanced creativity: A multiple case study of digital technology-integration expert teachers, beliefs and practices Enik o. 39(November 2020). https://doi.org/10.1016/j.tsc.2021.100791.

Brief, P. (2020). Policy Brief: Education during COVID-19 and beyond. August.

Cahyono, B. Y., Kurnianti, O. D., \& Mutiaraningrum, I. (2016). Indonesian Efl Teachers' Application Of Tpack In In-Service Education Teaching Practices Universitas Negeri Malang, Indonesia. International Journal of English Language Teaching, 4(5), 16-30.

Cerit, Y. (2013). Relationship between Teachers' Self-Efficacy Beliefs and Their Willingness to Implement Curriculum Reform. International Journal of Educational Reform, 22(3), 252-270. https://doi.org/10.1177/105678791302200304.

Ciptaningrum, D. S. (2017). The development of the survey of technology use, teaching, and technology-related learning experiences among pre-service English language teachers in Indonesia. Journal of Foreign Languange Teaching and Learning, 2(2), 11-26. https://doi.org/10.18196/ftl.2220.

Clark, H., Coll-Seck, A. M., Banerjee, A., Peterson, S., Dalglish, S. L., Ameratunga, S., Balabanova, D., Bhan, M. K., Bhutta, Z. A., Borrazzo, J., Claeson, M., Doherty, T., El-Jardali, F., George, A. S., Gichaga, A., Gram, L., Hipgrave, D. B., Kwamie, A., Meng, Q., ... Costello, A. (2020). A future for the world's children? A WHO-UNICEF-Lancet Commission. The Lancet, 395(10224), 605-658. https://doi.org/10.1016/S0140-6736(19)32540-1.

Dhawan, S. (2020). Online Learning: A Panacea in the Time of COVID-19 Crisis. Journal of Educational Technology Systems, 49(1), 5-22. https://doi.org/10.1177/0047239520934018.

Fiarman, S. E. (2016). Unconscious Bias: When Good Intentions Aren' t Enough The In uence of Bias. Educational Leadership, 74, 1-7.

Fitri, Y., \& Putro, N. H. P. S. (2021). EFL Teachers' Perception of the Effectiveness of ICT-ELT Integration During the COVID-19 Pandemic. Proceedings of the International Conference on Educational Sciences and Teacher Profession (ICETeP 2020), 532(532), https://doi.org/10.2991/assehr.k.210227.086.

Fuad, M., Ariyani, F., Suyanto, E., \& Shidiq, A. S. (2020). Exploring teachers' tpck: Are indonesian language teachers ready for online learning during the covid-19 outbreak? Universal Journal of Educational Research, 8(11B), 6091-6102. https://doi.org/10.13189/ujer.2020.082245.

Graham, L. J., White, S. L. J., Cologon, K., \& Pianta, R. C. (2020). Do teachers' years of experience make a difference in the quality of teaching? Teaching and Teacher Education, 96, 103190. https://doi.org/10.1016/j.tate.2020.103190.

Hussain, S., \& Javed, T. (2019). Determination of Motivational Behavior by Implementation of Theory of Planned Behavior: A Study on Teachers of Higher Education Sectors of Punjab. International Journal of Academic Research in Business and Social Sciences, 9(3), 1232-1249. https://doi.org/10.6007/ijarbss/v9-i3/5792.

Hyder, I., \& Bhamani, S. (2016). Bloom's Taxonomy (Cognitive Domain) in Higher Education Settings: Reflection Brief. Journal of Education and Educational Development, 3(2), 288. https://doi.org/10.22555/joeed.v3i2.1039.

Jihad Mohaidat, M. A. B. (2013). Technology Readiness of School Teachers - An Empirical Study of Measurement and Segmentation. Industrial Engineering \& Management, 02(04), 257-275. https://doi.org/10.4172/2169-0316.1000117.

Klimova, B. (2021). ScienceDirect An Insight into Online Foreign Language Learning and Teaching in the Era of COVID-19 Pandemic. Procedia Computer Science, 192, 1787-1794. https://doi.org/10.1016/j.procs.2021.08.183. 
Li, B. (2021). Ready for Online? Exploring EFL Teachers' ICT Acceptance and ICT Literacy During COVID-19 in Mainland China. Journal of Educational Computing Research, 073563312110289. https://doi.org/10.1177/07356331211028934.

Low, E. L., Ng, P. T., Hui, C., \& Cai, L. (2019). How do teacher affective and cognitive self-concepts predict their willingness to teach challenging students? Australian Journal of Teacher Education, 44(10), 1834. https://doi.org/10.14221/ajte.2019v44n10.2.

Maican, M. A., \& Cocoradă, E. (2021). Online foreign language learning in higher education and its correlates during the covid-19 pandemic. Sustainability (Switzerland), 13(2), 1-21. https://doi.org/10.3390/su13020781.

Nazari, N., Nafissi, Z., Estaji, M., Marandi, S. S., Nazari, N., Nafissi, Z., Estaji, M., Marandi, S. S., Nazari, N., Nafissi, Z., Estaji, M., \& Marandi, S. S. (2019). Evaluating novice and experienced EFL teachers ' perceived TPACK for their professional development Evaluating novice and experienced EFL teachers , perceived TPACK for their professional development. Cogent Education, 6(1). https://doi.org/10.1080/2331186X.2019.1632010.

Octaberlina, L. R., \& Muslimin, A. I. (2020). EFL Students Perspective towards Online Learning Barriers and Alternatives Using Moodle / Google Classroom during COVID-19 Pandemic. International Journal of Higher Education, 9(6), 1-9. https://doi.org/10.5430/ijhe.v9n6p1.

Oyedotun, T. D. (2020). Sudden change of pedagogy in education driven by COVID-19: Perspectives and evaluation from a developing country. Research in Globalization, 2(June), 100029. https://doi.org/10.1016/j.resglo.2020.100029.

Prasojo, L. D., Habibi, A., Mukminin, A., \& Yaakob, M. F. M. (2020). Domains of technological pedagogical and content knowledge: Factor analysis of indonesian in-service EFL teachers. International Journal of Instruction, 13(4), 593-608. https://doi.org/10.29333/iji.2020.13437a.

Rodríguez, S., Regueiro, B., Blas, R., Valle, A., Piñeiro, I., \& Cerezo, R. (2015). Teacher self-efficacy and its relationship with students' affective and motivational variables in higher education. European Journal of Education and Psychology, 7(2), 107. https://doi.org/10.30552/ejep.v7i2.106.

Savina, N. N. (2015). The Teachers' Willingness To Create Highly Intelligent Educational Innovations. Procedia - Social and Behavioral Sciences, 191, 2605-2608. https://doi.org/10.1016/j.sbspro.2015.04.252.

Schmidt, G. A., Ruedy, R. A., Miller, R. L., \& Lacis, A. A. (2010). Attribution of the present-day total greenhouse effect. Journal of Geophysical Research Atmospheres, 115(20), 1-6. https://doi.org/10.1029/2010JD014287.

Sharma, L., \& Srivastava, M. (2020). Teachers' motivation to adopt technology in higher education. Journal of Applied Research in Higher Education, 12(4), 673-692. https://doi.org/10.1108/JARHE-07-2018-0156.

Sieberer-Nagler, K. (2015). Effective Classroom-Management \& Positive Teaching. English Language Teaching, 9(1), 163. https://doi.org/10.5539/elt.v9n1p163.

Sobral, S. R. (2021). Bloom's taxonomy to improve teaching-learning in introduction to programming. International Journal of Information and Education Technology, 11(3), 148-153. https://doi.org/10.18178/ijiet.2021.11.3.1504.

Surayya, S. A., \& Asrobi, M. (2020). Tracing Technological Pedagogical Content Knowledge (TPACK) on Practical EFL Teachers in Writing Context. VELES Voices of English Language Education Society, 4(2), 177-190. https://doi.org/10.29408/veles.v4i2.2417.

Syahputra, Y. S., Santosa, R., \& Supriyadi, S. (2017). Teacher'S Willingness Towards the Implementation of Scientific Approach: From Theory To Implementation. Journal of English Education, 2(2), 132-137. https://doi.org/10.31327/jee.v2i2.409.

Teräs, M., Suoranta, J., Teräs, H., \& Curcher, M. (2020). Post-Covid-19 Education and Education Technology 'Solutionism': a Seller's Market. Postdigital Science and Education, 2(3), 863-878. https://doi.org/10.1007/s42438-020-00164-X.

Tovar Viera, R., \& Velasco Sánchez, D. I. (2020). Research on Technology Competencies in EFL Language Instructors: Technology-Pedagogy-Content in Language Teaching. Script Journal: Journal of Linguistics and English Teaching, 5(1), 32-43. https://doi.org/10.24903/sj.v5i1.414

Tseng, J.-J. (2014). Investigating EFL teachers' technological pedagogical content knowledge: Students' perceptions. 2014, 379-384. https://doi.org/10.14705/rpnet.2014.000249.

Utama, C. (2019). Analysis of Competence on “TPACK ”: 21st Century Teacher Professional Development Analysis of Competence o $n$ " T PACK ”: 21st Century Teacher Professional Development. https://doi.org/10.1088/1742-6596/1387/1/012035.

Wagner, H., Hahn, I., Schöps, K., Ihme, J. M., \& Köller, O. (2018). Are the tests scores of the Programme for International Student Assessment (PISA) and the National Educational Panel Study (NEPS) science tests comparable? An assessment of test equivalence in German Schools. Studies in Educational 
Evaluation, 59, 278-287. http://dx.doi.org/10.1016/j.stueduc.2018.09.002.

Wijaya, H., Tari, E., Sumule, L., Weismann, I. T. J., \& Supartini, T. (2021). Online Learning Evaluation in Higher Education: Study Survey Method. Journal of Education Technology, 5(3), 401-408. https://doi.org/10.23887/jet.v5i3.35466. 